\title{
LANDSCAPE CHANGES OF RURAL PROTECTED LANDSCAPE AREAS IN CZECHIA: FROM ARABLE LAND TO PERMANENT GRASSLAND - FROM OLD TO NEW UNIFICATION?
}

\author{
TOMÁŠ JANÍK ${ }^{1,3 *}$, HANA SKOKANOVÁ2 ${ }^{2}$ ROMAN BOROVEC ${ }^{2}$, \\ DUŠAN ROMPORTL ${ }^{1}$
}

\begin{abstract}
${ }^{I}$ Department of Spatial Ecology, The Silva Tarouca Research Institute for Landscape and Ornamental Gardening (VÚKOZ), Květnové námèstí 391, 25243 Průhonice, Czechia

${ }^{2}$ Department of Landscape Ecology, The Silva Tarouca Research Institute for Landscape and Ornamental Gardening (VÚKOZ), Lidická 25/27, 60200 Brno, Czechia

${ }^{3}$ Department of Physical Geography and Geoecology, Faculty of Science, Charles

University, Albertov 6, 12800 Praha 2, Czechia

*Corresponding author e-mail: Tomas.Janik@vukoz.cz
\end{abstract}

Received: $26^{\text {th }}$ August 2021, Accepted: $5^{\text {th }}$ October 2021

\begin{abstract}
The Czech rural landscape is a subject of research because it is affected by both intensification and extensification of land cover. This landscape was influenced in recent decades by political and socio-economic changes; we studied how these changes were reflected in the land cover development in protected areas. We selected ten Protected landscape areas (PLAs) with a significant share of open agricultural landscape and focused on land cover changes from the 1950s till the present with four milestones (1950s, 1990, 2004-2006, 2016-2019). Based on vectorised land cover data, analyses of land cover changes, land cover flows and landscape structure were performed.

More than one third of the studied area had changed. Forests dominated and enlarged its extent (from $39 \%$ to $47 \%$ ); land cover flow (LCF) from arable land to permanent grassland was the largest process during study period (17\% of study area) and it expanded after 1990. Other major LCF is forest spreading on permanent grassland $(5 \%)$ and arable land (3\%).

Trends of landscape metrics describing landscape structure are ambiguous and differ between PLAs. In total, Shannon's diversity index (SDI), Shannon's evenness index (SEI), and Mean Patch Size (MPS) increased and Number of Patches (NumP) decreased. SDI and SEI show improvement through time; however increasing anthropogenic areas are considered as factor contributing to this positive trend, despite the negative role of these categories in ecological stability. MPS and NumP show ongoing homogenization and unification of the landscape; however it differs between PLAs, with some having more favourable conditions and trends towards higher landscape heterogeneity.

To conclude, homogenous landscape structure remains present in Czech rural PLAs; however, there has been a huge shift to more extensive agricultural land cover, which is similar to some European protected areas.
\end{abstract}

Keywords: Land cover change; Landscape structure; Land cover flows; Protected landscape area; Czechia 


\section{INTRODUCTION}

Since 1950s, land cover changes have occurred on a significant part of Czechia (Feranec et al., 2010; Kupková et al., 2021). After World War II, urbanization, afforestation, and a decrease in arable land took place (Kupková et al., 2021). Basically, changes have resulted from two opposite processes - (sub)urbanization around built-up areas (Pazúr et al., 2017) and extensification of land cover in the form of grassing over and an increase in forest area (Kupková \& Bičík, 2016; Skokanová et al., 2016), especially in more peripheral areas (Antrop, 2005). These landscape changes are caused by several driving forces affected by political and economic transformations (Hampl \& Müller, 2011; Sýkora \& Bouzarovski, 2012; Skokanová et al., 2016), which are connected with regimes and their changes: socialism and communism during the second half of the $20^{\text {th }}$ century $(1948-1989)$, the collapse of communist regimes in Central Europe (1989/1990), emerging democracy and capitalism in the 1990s, and EU accession (2004) and membership (Žoncová, 2020).

Besides overall categorical changes in the extent of land cover, the Czech landscape also experienced change in landscape structure. This change is expressed as a shift from a small-scale heterogeneous landscape, typical for the pre-socialist period, to a more homogenous large-scale landscape as a legacy of the socialist era and agricultural collectivization (Sklenička et al., 2014). This is true for vast areas of the country, despite the fact that more than $15 \%$ of Czechia is protected by large protected areas (protected landscape areas and national parks) and the majority of them were established during the socialist era (Pešout, 2010). Protected landscape areas (PLAs) are characterized by "harmonious landscape development" and a "significant share of natural ecosystems" (Act No. 114/1992). Thus, not only natural but also anthropogenic values are objects of protection, such as architecture, urbanism, and landscape composition, i.e. landscape structure (Pešout, 2010). Protection status should therefore provide better landscape functionality based on landscape structure, as was explored in some examples (Skokanová \& Eremiášová, 2013).

The extent of protected areas has significantly increased worldwide in recent decades (Naughton-Treves et al., 2005) and in Czechia as well. Protected areas are crucial for ensuring ecosystem services and biodiversity, as well as other natural values (Lehtomäki \& Moilanen, 2013). However, nature and landscape protection is not the only public interest in the protected areas. There is also interest in regional development, but this contradiction brings conflicts to the protected areas (Brandon \& Wells, 1992; Pietrzyk-Kaszynska et al. 2012). Therefore, protected areas also face land cover change (Žoncová, 2020), which can worsen the provision of ecosystem functions and can contribute to biodiversity loss (Brooks et al., 2002; Romportl, 2017).

While during the socialist era, the Czech countryside (and especially less-favoured areas) obtained politically motivated agricultural subsidies to intensify agricultural use (Bičík \& Jančák, 2001; Kümmerle et al., 2008), after 1990, agro-environmental programmes, especially from the EU Common Agricultural Policy (CAP), were used to replace intensive agriculture with extensification activities, such as grassing over (Bičík \& Jančák, 2005; Skokanová et al., 2016; Havlíček et al., 2018).

The aim of this article is to analyse the development of land cover and landscape structure in the selected PLAs in Czechia, characterized by a large share of agricultural land. In particular, it will focus on the following questions: 1) was land use intensification and homogenization of the landscape structure typical for the socialist era present in PLAs? 2) have these processes continued towards the present, despite establishing new protected areas and improved environmental policy since the 1990s? 3) and, if so, in what form? 
Janík T., Skokanová H., Borovec R., Romportl D.: Landscape changes of rural protected landscape areas in Czechia: From arable land to permanent grassland - from old to new unification?

\section{MATERIAL AND METHODS}

\section{Study area}

Ten PLAs were selected for the analyses (Tab. 1, Fig. 1). They were characterized as rural and were defined by the following criteria:

1) forests occupy less than $60 \%$ of the area in each time horizon,

2) arable land, permanent grassland, vineyards and hop gardens, gardens and orchards together make up more than $30 \%$ of area in each time horizon,

3) exclusion of mountainous PLAs and National Parks (NPs) with the highest point over $1100 \mathrm{~m}$ a.s.l.,

4) the total extent of a PLAs is larger than $85 \mathrm{~km}^{2}$.

Table 1: Characteristics of studied protected landscape areas (PLAs)

\begin{tabular}{lllll}
\hline PLA & $\begin{array}{l}\text { year of } \\
\text { establishment }\end{array}$ & $\begin{array}{l}\text { area } \\
{\left[\mathrm{km}^{2}\right]}\end{array}$ & $\begin{array}{l}\text { elevation range } \\
{[\mathrm{m} \text { a.s.l.] }}\end{array}$ & $\begin{array}{l}\text { mean elevation } \\
{[\mathrm{m} \text { a.s.1.] }}\end{array}$ \\
\hline Bílé Karpaty & 1980 & 747 & $171-970$ & 439 \\
\hline Blanský les & 1989 & 220 & $420-1087$ & 634 \\
\hline Broumovsko & 1991 & 432 & $357-880$ & 516 \\
\hline Český kras & 1972 & 132 & $208-499$ & 345 \\
\hline Český ráj & 1955 & 182 & $235-744$ & 330 \\
\hline České středohoř́ & 1976 & 1069 & $122-837$ & 366 \\
\hline Pálava & 1976 & 85 & $153-544$ & 254 \\
\hline Slavkovský les & 1974 & 610 & $374-983$ & 668 \\
\hline Žd'árské vrchy & 1970 & 709 & $490-836$ & 644 \\
\hline Železné hory & 1991 & 285 & $268-668$ & 502 \\
\hline
\end{tabular}

\section{Data}

We used land cover data derived from topographical maps and aerial imagery that capture milestones for land cover and land use development in recent history, as well as for nature protection. These milestones are: a) 1950s as the beginning of the socialist era and also the founding of the first PLAs, b) around the year 1990 as a transformation from socialism and communism to a free market economy, capitalism, and democracy, as well as new environmental legislation (Act No. 114/1992), c) around 2004 as EU accession, together with requirements of EU legislation, and d) 2016-2019 as the present state. Nine categories of land cover (Tab. 2) were distinguished according to various sources (topographical maps, aerial imagery) which were used. Data were manually vectorised in ArcGIS 10.5 software (ESRI) with a minimum area of 0.8 ha and a minimum width of $40 \mathrm{~m}$ for each patch from the mentioned sources. These criteria were set with regard to output scale. 


\section{Fig. 1: Studied protected landscape areas (PLAs) in Czechia}

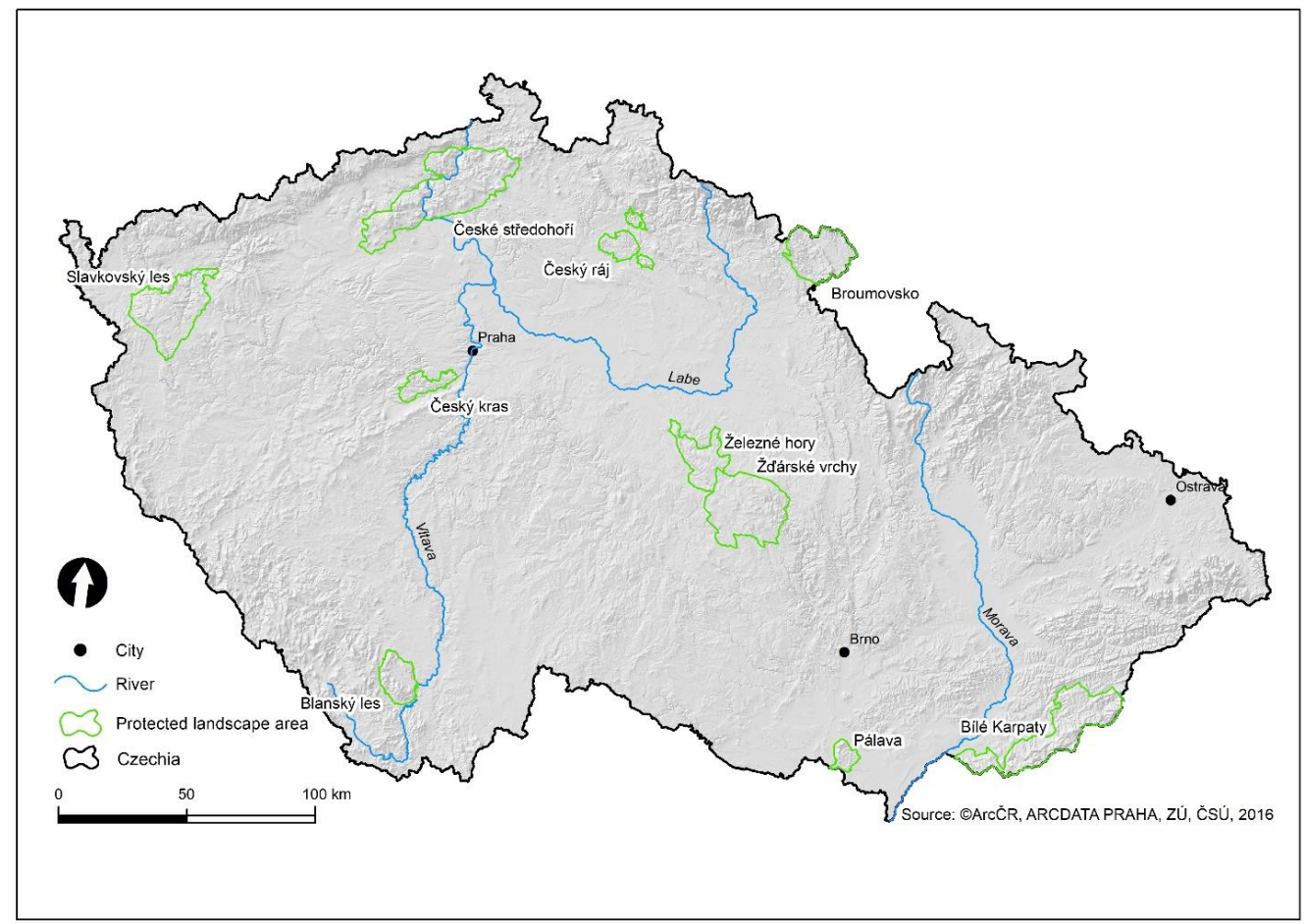

Table 2: Description of land cover categories

\begin{tabular}{ll}
\hline Land cover category & Description \\
\hline Other area & Mining area, dump sites, development areas \\
\hline Arable land & Arable fields, mosaics of fields, trees and small vineyards, fallow land \\
\hline $\begin{array}{l}\text { Permanent } \\
\text { grassland }\end{array}$ & Meadows, pastures, steppes, moors, grasslands \\
\hline Garden and orchard & Intensive and extensive orchards, large gardens adjacent to built-up areas \\
\hline Vineyard and hop & Small and large scale, facility included \\
garden & \\
\hline Forest & Forest, non-forest woody vegetation, mountain pine, shrubs, forest nurseries \\
\hline Water area & Ponds, lakes, dams, pools, flooded mining areas \\
\hline Built-up area & Continuous and dispersed built-up area, industrial and military areas \\
\hline Recreational area & Cottages, recreational objects, golf courses, camps \\
\hline
\end{tabular}




\section{Methods}

General trends in the total share of land cover categories for all PLAs together and for all four time horizons were analysed. For visualising land cover change, a principal component analysis (PCA) in R software (R Core Team 2019) was used.

To evaluate and define changes among land cover categories, the concept of so-called land cover flows (LCF) was used (EEA, 2006; Feranec et al., 2010; Martinez-Fernandez et al., 2015). Only overall changes above $1 \%$ were considered. Furthermore, LCF areas for both the whole group and for each PLA were compared in two periods: 1950s-1990 and 1990-present. In these two periods, stable and changed land cover were also evaluated for the whole group as well as individual PLAs. Wilcoxon signed rank test in $\mathrm{R}$ was used for evaluation of differences between areas of LCF in the two periods.

To compare changes in landscape structures, several easy-to-evaluate landscape metrics were chosen: Shannon's diversity index $(S D I)$, Shannon's evenness index (SEI), number of patches $(N u m P)$, mean patch size $(M P S)$, and edge density $(E D)$. SDI assesses land cover diversity by the number of land cover categories and number of patches, while $S E I$ is an index showing evenness of distribution of patches in individual land cover categories. NumP and MPS are metrics demonstrating whether homogenization and unification of the landscape is taking place. Finally, $E D$ evaluates the complexity of shape of the patches and is comparable between landscapes of varying size (McGarigal \& Marks, 1994; Uuemaa et al., 2009). For computation of landscape metrics, Patch Analyst (Elkie et al., 1999), extension for ArcGIS, was used.

\section{RESULTS}

\section{Land cover change}

In total, area of $4471.3 \mathrm{~km}^{2}$ of the landscape within the ten PLAs was investigated. There is a clear shift from arable land and more intensive agriculture to less intensive agriculture land cover with an increased share of permanent grassland as well as forest area during the study period. On the other hand, built-up and recreational areas increased as well. In 1950s, forest was the most widespread category (39.2\%), followed by arable land (36.8 \%) and permanent grassland (18\%). It has gradually changed: from 1950s to 1990 forested area increased with a share of $44 \%$ in 1990 and arable land decreased to $30.8 \%$, while permanent grassland remained almost same (17.2\%). After 1990, forest still dominated $(45.3 \%$ in 2006 and $47.3 \%$ at present), permanent grassland grew (22.1\% in 2006 and $27.8 \%$ at present), and arable land shrunk (24.1\% in 2006 and $15.8 \%$ at present). Also, built-up areas increased gradually $(4.1 \%-5.5 \%-5.9 \%-6.5 \%)$; it is approximately $0.5 \%$ of the whole study area per 10 years. The landscape development described above is clearly visible from Fig. 2, especially the change from arable land to permanent grassland. 
Fig. 2: PCA analysis showing land cover change. The trends of changes of land cover categories are shown by arrows, especially shift from arable land in the past to permanent grassland nowadays is visible.

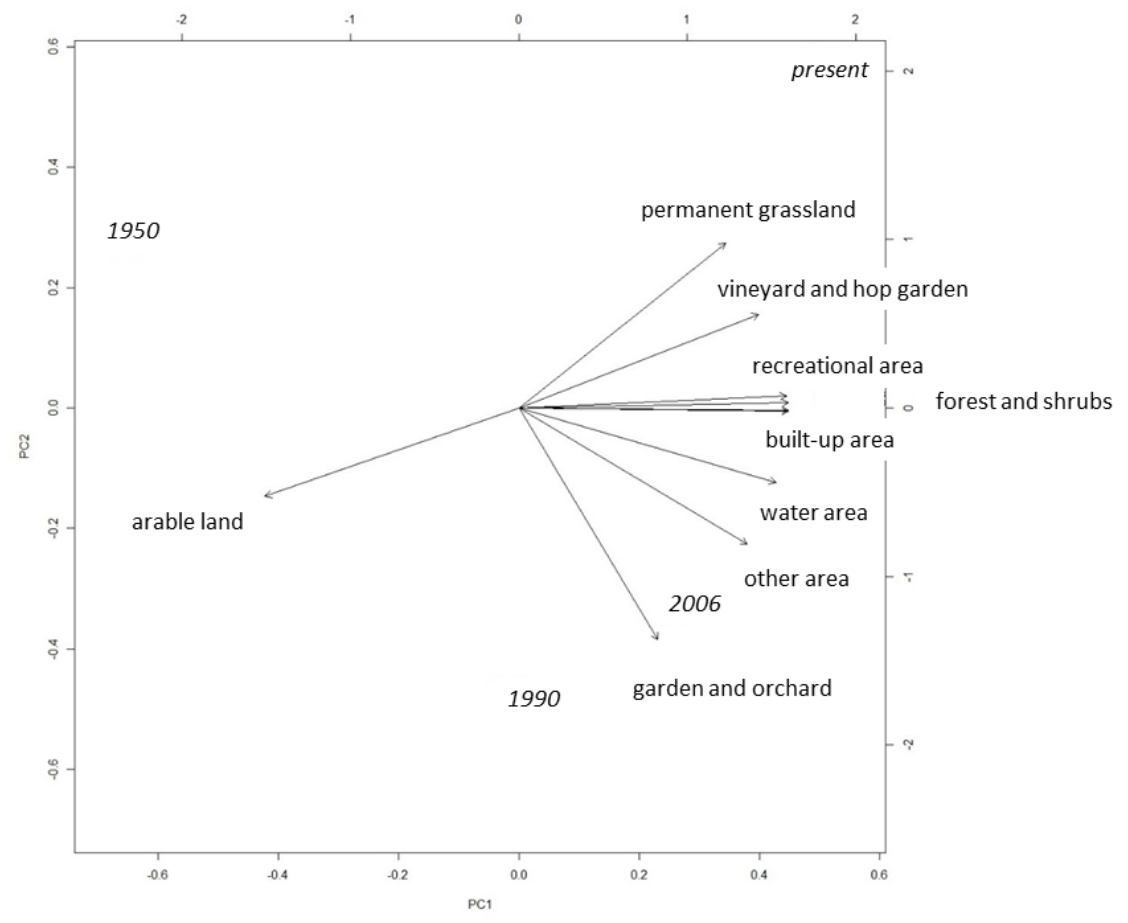

\section{Land cover flows}

In total, land cover flow (LCF) from arable land to permanent grassland is the largest (16.7\% of the area of all PLAs for whole study period, i.e. 1950-present). The second and third largest LCF for the whole study period were forest increases from permanent grassland and arable land. LCF larger than $1 \%$ of the study area in whole study period are also represented by LCF from arable land to built-up area and LCF from permanent grassland to arable land (Tab. 3).

The comparison of LCF in the period from 1950s to 1990 and from 1990 to present (which are similar in duration and the year 1990 is a main breaking point in our study period) reveals the following (Tab. 3): The main LCF from arable land to permanent grassland increased extensively; on the other hand, LCF from permanent grassland and LCF from arable land to forest decreased. Other LCF were smaller than $1 \%$ in the 1990-present period, showing a reducing number of significant LCF to only a few processes. For example, LCF from permanent grassland to arable land was $5 \%$ in 1950 s- 1990 period and only $0.7 \%$ after 1990 ; furthermore LCF from arable land to built-up area was $1.2 \%$ in $1950 \mathrm{~s}-1990$ period and only $0.6 \%$ in 1990 present period. Despite the differences between these two periods in the largest LCFs, the areas of all individual LCF are not significantly different (Wilcoxon signed rank test, $\mathrm{p}$-value $=0.0909$, sig. level 0.05). 
Janík T., Skokanová H., Borovec R., Romportl D.: Landscape changes of rural protected landscape areas in Czechia: From arable land to permanent grassland - from old to new unification?

Table 3: Land cover flows larger than $1 \%$ of study area in all PLAs for selected time periods

\begin{tabular}{|c|c|c|c|}
\hline Land cover flows larger than $1 \%$ of study area & $\begin{array}{l}\text { Whole study } \\
\text { period (\%) }\end{array}$ & $\begin{array}{l}\text { 1950s-1990 } \\
(\%)\end{array}$ & $\begin{array}{l}\text { 1990-present } \\
(\%)\end{array}$ \\
\hline Arable land to permanent grassland & 16.7 .0 & 7.5 & 13.9 \\
\hline Permanent grassland to forest & 5.2 & 3.5 & 3.2 \\
\hline Arable land to forest & 3.4 & 2.1 & 1.1 \\
\hline Arable land to built-up area & 1.8 & 1.2 & \\
\hline Permanent grassland to arable land & 1.6 & 5.0 & \\
\hline
\end{tabular}

Analyses of LCF in individual PLAs revealed the dominance of LCF from arable land to permanent grassland, with the exception of Pálava PLA. In Pálava, arable land was predominantly changed to vineyards. The second most spread LCF in five PLAs (Bílé Karpaty, Blanský les, České středohoří, Slavkovský les, Žd'árské vrchy) was from permanent grassland to forest, while in three (Broumovsko, Český kras, Český ráj) it was from arable land to forest. Other LCF larger than $1 \%$ of the area represented in all PLAs are LCF from arable land to forest and from arable land to built-up area.

Comparing the periods 1950s-1990 and 1990-present shows an increase in LCF of arable land to permanent grassland. The only exception is Broumovsko PLA where this process was bigger during the 1950s-1990 period than in 1990-present. Generally, there is a shift from many relatively large LCF during 1950s-1990 to dominant LCF from arable land to permanent grassland in period 1990-present (see appendix A).

\section{Stability and change in land cover}

In the studied PLAs, approximately one third of the area had changed, while $38.4 \%$ of the area remained as forest, $13.7 \%$ as arable land, $10.0 \%$ as permanent grassland, and $3.5 \%$ as built-up areas (Fig. 3). During the first period (1950s-1990), about a quarter of the area changed, which means that less than $1 \%(0.7 \%)$ of the area changed per year on average. In the second period, from 1990 to 2006, about $17.3 \%$ changed, leading to a change of $1.1 \%$ of the total area per year. The same change rate per year occurred in the last and most recent period (2006-present). However, considering the period 1990-present, the change is almost the same $(24.41 \%)$ as in the $1950 \mathrm{~s}-1990$ period $(24.40 \%)$. 
Fig. 3: Stability of the land cover categories (\%) for all PLAs in total and the whole study period (1950s - present)

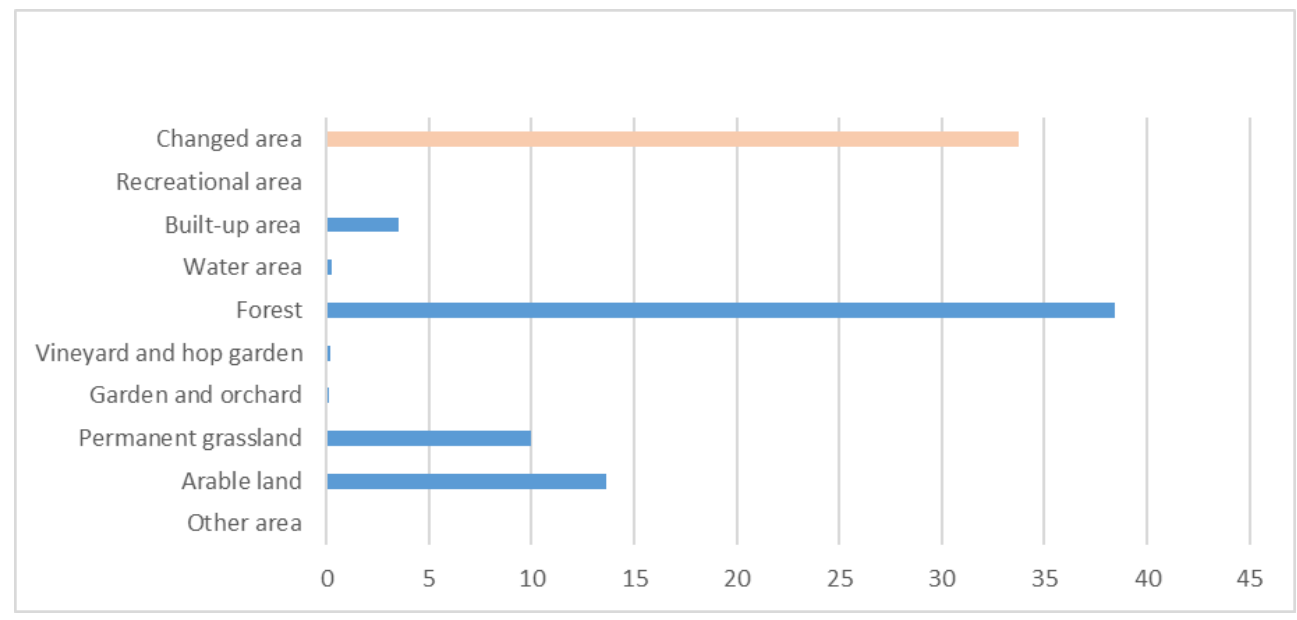

The proportion of changed and stable land cover varied between PLAs. The minimum area with stable land cover was noted in České středohoří (49.6 \%), followed by Pálava ( $56.7 \%)$, Broumovsko (57.1\%), Bílé Karpaty (57.7\%), and Slavkovský les (58.0\%). A PLA with higher stable land cover is represented by Český ráj (63.5\%), while the stability of land cover is the highest in Železné hory (66.9\%), Blanský les (68.6 \%), Žd'árské vrchy (69.8\%), and Český kras $(72.3 \%)$.

\section{Landscape structure and metrics}

The development of landscape structure was analysed with several metrics (Table 4). Shannon's diversity and evenness index increased over the first study period and mean patch size in the whole period. On the other hand, the number of patches and edge density decreased. Changes in the indices varied between categories; for example, mean patch size of arable land increased in the period 1950s-1990 and then decreased, while edge density and number of patches in this category steadily decreased over time. On the other hand, both mean patch size and edge density of permanent grassland increased ( $E D$ was the lowest in 1990), especially after 1990. The number of patches as well as edge density of forest increased, while mean patch size is almost similar throughout the time. Built-up area experienced increased edge density, mean patch size, and number of patches (see appendix B).

Table 4: Selected landscape metrics for all PLAs, whole landscape, and time periods. SDI - Shannon's diversity index, SEI - Shannon's evenness index, ED - edge density, MPS - mean patch size, NumP - number of patches

\begin{tabular}{lccccc}
\hline Time horizon & SDI & SEI & ED & MPS & NumP \\
\hline $\mathbf{1 9 5 0 s}$ & 1.27 & 0.58 & 97.27 & 26.86 & 16646 \\
\hline $\mathbf{1 9 9 0}$ & 1.31 & 0.60 & 93.58 & 27.72 & 16131 \\
\hline Present & 1.31 & 0.60 & 88.33 & 29.78 & 15015
\end{tabular}


Janík T., Skokanová H., Borovec R., Romportl D.: Landscape changes of rural protected landscape areas in Czechia: From arable land to permanent grassland - from old to new unification?

An overview of changes in landscape structure measured by landscape metrics in individual PLAs is shown in Table 5. In five of ten PLAs, the number of patches steadily decreased (Blanský les, Broumovsko, České středohoří, Slavkovský les, Železné hory), while in three there was a continuous increase (Bílé Karpaty, Pálava, Žd'árské vrchy) and in two the peak of number of patches was noted in 1990 (Český kras, Český ráj). Similarly, edge density increased in four PLAs (Bílé Karpaty, Český kras, Český ráj - but the highest was in 1990, Pálava) and decreased in six (Blanský les, Broumovsko, České středohoří, Slavkovský les, Žd'árské vrchy, Železné hory). Shannon's diversity and evenness indexes increased in all areas except Blanský les (SDI increased with peak already in 1990 and SEI decreased), Broumovsko (both increased with peak already in 1990) and Slavkovský les (both SDI and SEI decreased). 
Table 5: Landscape metrics and their development in time horizons 1950s-1990-present for all study areas and PLAs. SDI - Shannon's diversity index, SEI - Shannon's evenness index, ED - edge density, MPS - mean patch size, NumP - number of patches

\begin{tabular}{|c|c|c|c|c|c|c|c|c|c|c|}
\hline $\begin{array}{l}\text { Landscape } \\
\text { metrics }\end{array}$ & $\begin{array}{l}\text { Bílé } \\
\text { Karpaty }\end{array}$ & Blanský les & Broumovsko & $\begin{array}{l}\text { České } \\
\text { středohoří }\end{array}$ & Český kras & Český ráj & Pálava & $\begin{array}{l}\text { Slavkovský } \\
\text { les }\end{array}$ & $\begin{array}{l}\text { Žd'árské } \\
\text { vrchy }\end{array}$ & $\begin{array}{l}\text { Železné } \\
\text { hory }\end{array}$ \\
\hline SDI & increase & $\begin{array}{l}\text { increase - } \\
\text { peak in } 1990\end{array}$ & $\begin{array}{l}\text { increase - peak } \\
\text { in } 1990\end{array}$ & increase & increase & increase & increase & decrease & increase & increase \\
\hline SEI & increase & decrease & $\begin{array}{l}\text { increase - peak } \\
\text { in } 1990\end{array}$ & increase & increase & increase & increase & decrease & increase & increase \\
\hline ED & increase & decrease & decrease & decrease & increase & $\begin{array}{l}\text { increase - } \\
\text { peak in } 1990\end{array}$ & increase & decrease & $\begin{array}{l}\text { decrease - } \\
\text { minimum in } \\
1990\end{array}$ & decrease \\
\hline MPS & decrease & increase & increase & increase & $\begin{array}{l}\text { decrease - } \\
\text { minimum } \\
1990\end{array}$ & $\begin{array}{l}\text { decrease - } \\
\text { minimum in } \\
1990\end{array}$ & decrease & increase & $\begin{array}{l}\text { decrease - } \\
\text { but peak in } \\
1990\end{array}$ & $\begin{array}{l}\text { increase - } \\
\text { peak in } 1990\end{array}$ \\
\hline NumP & increase & decrease & decrease & decrease & $\begin{array}{l}\text { increase - } \\
\text { peak in } 1990\end{array}$ & $\begin{array}{l}\text { increase - } \\
\text { peak in } 1990\end{array}$ & increase & decrease & increase & decrease \\
\hline
\end{tabular}


Janík T., Skokanová H., Borovec R., Romportl D.: Landscape changes of rural protected landscape areas in Czechia: From arable land to permanent grassland - from old to new unification?

\section{DISCUSSION}

\section{Land cover trends}

The analyses presented here revealed trends typical for the majority of regions with less favourable conditions in Europe (Munteanu et al., 2014), including Czechia (Havlíček et al., 2018), especially during the past 30 years. These trends are afforestation/landscape abandonment connected with an increase in woody vegetation (e.g. Pazúr \& Bolliger, 2017; Kolecka et al., 2017) and agricultural extensification expressed by expansion of permanent grassland to the detriment of arable land (Lieskovský \& Lieskovská, 2021). Afforestation in the PLAs was more widespread during 1950-1990 and forest spread both on arable land and permanent grassland (see Table 3). This could be a result of establishing PLAs during the second half of the 20th century, but also of expulsion of Czech Germans after 1945 in Sudeten PLAs such as Blanský les, Broumovsko, České středohoří, or Slavkovský les (Kupková et al., 2013). On the other hand, agricultural extensification was more pronounced after 1990. It was driven by changed agricultural policy to less intensive management supported by agri-environmental schemes, mainly by grassing former arable land (Havlíček et al., 2018). Similar trends were typical for all areas with less favourable conditions, not only in Czechia (Štych et al., 2019) but also in Slovakia (Bezák \& Mitchley, 2014).

Agricultural intensification during the socialist era (Bičík \& Jančák 2001; Kümmerle et al., 2008), demonstrated as an increase in the area of arable land and other agricultural land cover categories like vineyards and orchards, was typical mainly for lowland and mid-altitudes regions of Czechia (Havlíček et al., 2014). In our study, it was absent even in the studied PLAs that can be considered as agriculturally more-favoured regions (Český ráj, Český kras, and České středohoří). The exception was Pálava PLA, where the amount of agricultural land remained more or less the same during this period. This was due to agricultural specialization focusing on wine production thanks to favourable abiotic conditions. Because of these conditions, this trend also continued after 1990 and was even the most widespread one in the PLA. In the more upland PLAs, agricultural intensification was largely absent, which corresponds with general trends captured for this type of landscape (Kupková et al., 2021) and are affected by less favourable biophysical factors (Opršal et al., 2016).

All PLAs were affected by increased anthropogenic pressure in the form of expansion of built-up and recreational areas. It differentiated between periods as well as between the PLAs (see appendix A). In general, it was higher during the socialist period thanks to the spread of built-up areas, despite the protection status. This trend was common for the whole of Czechia (Štych et al., 2019; Kupková et al., 2021); however, it was less pronounced in PLAs than in non-protected areas (Jačková et al., 2011). Pressure in the form of recreational areas was not as pronounced as in mountainous PLAs (Janík et al., 2019; Janík et al., 2020).

The trends described did not affect the whole area of the PLAs but occurred on more territory even in Central Europe. For example, the dominance of stable forest areas and their increase were typical not only for the studied PLAs but also for other regions in Czechia, as well as Slovakia, from the mountains (Janík et al., 2019; Janík et al., 2020; Skokanová \& Havlíček, 2018) to the lowlands (e.g. Havlíček et al., 2014; Kilianová et al., 2017). Generally, extensification of land cover in the form of forest expansion was also observed in Slovakian (Žoncová, 2020; Olah \& Boltižiar, 2009) and other European protected areas (Hellwig et al., 2019). It should be stressed that the main process in the studied rural PLAs is change from arable land to permanent grassland. This fact can be attributed to the prevailing agricultural character of the PLAs being more prone to change than forested landscape. Indeed, PLAs with higher forest cover have larger stable areas, which are usually formed by forested land (Fig. 3). 


\section{Land cover structure}

There is an overall increase in SDI and SEI, showing a more heterogeneous landscape in terms of various land cover categories (Table 4,5). However, this fact was highly affected by the introduction of an increase in anthropogenic categories - recreational as well as built-up areas, i.e. categories that usually have a negative impact on biodiversity and ecological stability (Kuussaari et al., 2020; Michaeli et al., 2015).

Landscape metrics representing homogenization of the landscape structure (i.e. decreasing number of patches $(N u m P)$, increasing mean patch size (MPS), and decreasing edge density (ED) show a rising trend for the landscape as a whole (Table 4), confirming steady homogenization of the landscape from 1950 onwards. This is clearly a result of socialist agricultural policy during the 1950-1990 period (Sklenička et al., 2014) and productivist agriculture that was introduced after 1990 (Skokanová et al., 2016). Changes in the metrics of individual land cover categories show that, despite significant decrease in arable land (and consequent changes in landscape metrics of the category) after 1990, homogenization of the landscape has continued, with permanent grassland replacing arable land.

There are obvious differences between PLAs (Table 5). With the exception of České středohoří and Slavkovský les, PLAs established during 1955-1980 show a trend towards larger heterogeneity of the landscape, especially during the 1950-1990 period, while the youngest PLAs (Blanský les, Broumovsko, and Železné hory), together with České středohoří and Slavkovský les, show a trend towards landscape homogenization. Homogenization in the youngest PLAs during the socialist era is not so surprising as these PLAs were not protected at the time and therefore no protection restrictions were applied. A certain trend towards homogenization after 1990 can be seen not only in the mentioned PLAs but also in Český kras and Český ráj. This is in contrast with the initial assumption that improved environmental policy after 1990 contributes to higher landscape heterogeneity. This trend of change to ecological more stable land cover categories but also to homogenization can be seen in other PLA as well, e.g., mountainous as Jeseníky and it can be insufficient for preserving biodiversity (Dostál et al., 2020).

We can say that the results presented here correspond with Jačková et al. (2011) who, when comparing landscape structure development inside and outside protected areas, found increasing homogenization of the landscape regardless of its protection status. However, as with her findings, it must be stressed that the results regarding landscape structure might be somewhat biased due to the spatial parameters of the data and sources used, which cannot capture detailed landscape microstructure.

\section{CONCLUSION}

Our results show a relatively big land cover change, especially from arable land to permanent grassland and forest. It implies that protection status might affect land cover changes to some degree and lessen anthropogenic pressure in the form of intensive agriculture in selected rural PLAs. General trends in forest increase and expansion of permanent grassland, typical for less favourable areas, played a significant role in the land cover changes of the studied PLAs. In particular, LCF from arable land to permanent grassland, which is even more pronounced after 1990, characterizes the given study period.

While the landscape composition of PLAs largely changed towards more ecologically stable land cover categories, such as forests and grasslands, landscape structure in the larger part of the studied PLAs still remains homogenous and this situation has even worsened since 1990. Despite these ongoing general processes, which show signs of simplification of landscape even after improved environmental policy after 1990, there are also PLAs with 
Janík T., Skokanová H., Borovec R., Romportl D.: Landscape changes of rural protected landscape areas in Czechia: From arable land to permanent grassland - from old to new unification?

favoured land cover and landscape structure development. Landscape change continues, and by using suitable legislative tools we can improve the rest of our landscape as well.

\section{ACKNOWLEDGMENT}

We would like to thank to Ministry of the Environment of the Czech Republic for supporting the project of Landscape monitoring (Biological research and monitoring in Czech Republic - providing scientific support for Environment 2018-2022 (contract no. 0113/17/900), part $D$ - Changes in landscape and trends in landscape changes). This work was also supported by the Faculty of Science, Charles University, grant SVV 244-2605731. We also appreciate work of all our colleagues, who helped us with data preparation.

\section{CONFLICT OF INTEREST}

The authors declare no conflict of interest.

\section{REFERENCES}

Act No. 114/1992 Call. On nature conservation and Landscape protection.

Antrop, M., (2005). Why landscapes of the past are important for the future. Landscape and Urban Planning 70, 21-34. https://doi.org/10.1016/j.landurbplan.2003.10.002.

Bezák, P., Mitchley, J., (2014). Drivers of change in mountain farming in Slovakia: from socialist collectivisation to the Common Agricultural Policy. Regional Environmental Change 14, 1343-1356. http://dx.doi.org/10.1007/s10113-013-0580-x.

Bičík I., Jančák V., (2001). Czech Agriculture after 1990. Geografie 106(4), 209-221

Bičík I., Jančák V., (2005). Transformační procesy v českém zemědělství po roce 1990 (Transformation processes in the Czech agriculture after 1990). Př́rodovědecká fakulta Univerzity Karlovy, Praha.

Brandon K. E. \& Wells, M., (1992). Planning for People and Parks: Design Dilemmas. World Development. Volume 20(4), 557-570.

Brooks T. M., Mittermeier R. A., Mittermeier C. G., Da Fonseca G. A. B., Rylands A. B., Konstant W. R., Flick P., Pilgrim J., Oldfield S., Magin G. \& Hilton-Taylor C., (2002). Habitat Loss and Extinction in the Hotspots of Biodiversity. Conservation Biology 16(4), 909-923. https://doi.org/10.1046/j.1523-1739.2002.00530.x.

Dostál A., Machar, I., Mackovčin P. (2020). Changes in the secondary landscape structure in Hruby Jesenik mountains (Czech Republic). Journal of Landscape Ecology 13(3), 107-121. https://doi.org/10.2478/jlecol-2020-0019.

Elkie, P. C., Rempel, R. S., Carr, A. P., (1999). Patch Analyst User's Manual. A tool for Quantifying Landscape Structure. Ontario Ministry of Natural Resources. Northwest Science and Technology Thunder Bay Ontario.

European environmental agency (EEA), (2006). Land accounts for Europe 1990-2000. Towards integrated land and ecosystem accounting. 107. ISBN 92-9167-888-0.

Feranec, J., Jaffrain, G., Soukup, T., \& Hazeu, G., (2010). Determining changes and flows in 
European landscapes 1990-2000 using CORINE land cover data. Applied Geography 30(1), 19-35. https://doi.org/10.1016/j.apgeog.2009.07.003.

Hampl, M., Müller, J., (2011). Společenská transformace a regionální diferenciace Česka: př́klad vývoje rozmístění pracovních míst a obyvatelstva [Societal Transformation and Regional Differentiation in Czechia: Developments in the Distribution of Job Opportunities and Population]. Geografie, 116(3), 211-230.

Havlíček M., Pavelková R., Frajer J., Skokanová H., (2014). The long-term development of water bodies in the context of land use: The case of the Kyjovka and Trkmanka River Basins (Czech Republic). Moravian Geographical Reports, 22(4), 39-50. DOI: 10.1515/mgr-2014-0022

Havlíček, M., Skokanová, H., Dostál, I., Vymazalová, M., Pavelková, R., Petrovič, F., (2018). The consequences of establishing military training areas for land use development A case study from Libavá, Czech Republic. Land Use Policy 73, 84-94. DOI: 10.1016/j.landusepol.2018.01.039

Hellwig, N., Walz, A., Markovic., D., (2019). Climatic and socioeconomic effects on land cover changes across Europe: Does protected area designation matter? Plos One. https://doi.org/10.1371/journal.pone.0219374

Jačková, K., Chuman, T., Romportl, D., (2011). Comparison of land cover changes in protected and unprotected sites on the outskirts of Prague metropolis (the Czech Republic), 1990-2006. AUC Geographica, 46, 67-79.

Janík, T., Zýka, V., Skokanová, H., Borovec, R., Demková, K., Havlíček, M., Chumanová, E., Houška, J., Romportl, D., (2019). Vývoj krajiny na území NP a CHKO Šumava od 50. let do současnosti [Landscape development on the territory of the NP and PLA Šumava since the 1950s till present]. Silva Gabreta, 50, 1-14.

Janík, T., Zýka, V., Skokanová, H., Borovec, R., Demková, K., Havlíček, M., Chumanová, E., Houška, J., Romportl, D., (2020). Vývoj krkonošské krajiny - od založení Krkonošského národního parku po součanost [Landscape development in the Krkonoše Mts: from foundation of the Krkonoše Mts National Park till present]. Opera Corcontica, 57, 65-76.

Kilianová, H., Pechanec, V., Brus, J., Kirchner, K., Machar, I., (2017). Analysis of the development of land use in the Morava River floodplain, with special emphasis on the landscape matrix. Moravian Geographical Reports, 25, 46-59. DOI: 10.1515/mgr-2017-0005

Kolecka, N., Kozak, J., Kaim, D., Dobosz, M., Ostafin, K., Ostapowicz, K., Wezyk, P., Price, B., (2017). Understanding farmland abandonment in the Polish Carpathians. Applied Geography 88, 62-72. DOI: 10.1016/j.apgeog.2017.09.002

Kümmerle, T., Hostert P., Radeloff V.C., PerzanowskI K. \& Kruhlov I., (2008). Cross-border comparison of post-socialist farmland abandonment in the Carpathians. Ecosystems 11, 614-628. https://doi.org/10.1007/s10021-008-9146-z.

Kupková, L., Bičík, I., Najman, J., (2013). Land Cover Changes along the Iron Curtain 1990 - 2006. Geografie, 118(2), 95-115.

Kupková L., Bičík I., (2016). Landscape transition after the collapse of communism in Czechia. Journal of Maps 12, 526-531, DOI: 10.1080/17445647.2016.1195301.

Kupková, L., Bičík I., Jeleček, L., (2021). At the Crossroads of European Landscape Changes: Major Processes of Landscape Change in Czechia since the Middle of the 19th Century and Their Driving Forces, Land 10(1), (34), 10.3390/land10010034.

Kuussaari, M., Toivonen, M., Heliölä, J., Pöyry, J., Mellado, J., Ekroos, J., Hyyryläinen, V., 
Janík T., Skokanová H., Borovec R., Romportl D.: Landscape changes of rural protected landscape areas in Czechia: From arable land to permanent grassland - from old to new unification?

Vähä-Piikkiö, I., Tiainen, J., (2020). Butterfly species' responses to urbanization: different effects of human population density and built-up area. Urban Ecosystems 24, 515-527. https://doi.org/10.1007/s11252-020-01055-6.

Lehtomäki, J., Moilanen, A., (2013). Methods and workflow for spatial conservation prioritization using Zonation. Environmental Modelling \& Software 47, 128-137. https://doi.org/10.1016/j.envsoft.2013.05.001.

Lieskovský, J., Lieskovská, D., (2021). Cropland abandonment in Slovakia: Analysis and comparison of different data sources. Land 10. https://doi.org/10.3390/land10040334

Martinez-Fernandez, J., Ruiz-Benito, P., Zavala, M., A., (2015). Recent land cover changes in Spain across biogeographical regions and protection levels: Implications for conservation policies. Land Use Policy 44, 62-75. https://doi.org/10.1016/j.landusepol.2014.11.021.

McGarigal, K., Marks, B. J., (1995). FRAGSTATS: spatial pattern analysis program for quantifying landscape structure. Gen. Tech. Rep. PNW-GTR-351. Portland, OR: U.S. Department of Agriculture, Forest Service, Pacific Northwest Research Station. 122 p.

Michaeli, E., Ivanová, M., Koco, Š., (2015). The evaluation of anthropogenic impact on the ecological stability of landscape. Journal of Environmental Biology, 36, 1-7

Munteanu, C., Kuemmerle, T., Boltižiar, M., Butsic, V., Gimmi, U., Halada, L., H., Kaim, D., Király, G., Konkoly-Gyuró, É., Kozak, J., Lieskovský, J., Mojses, M., Müller, D., Ostafin, K., Ostapowicz, K., Shandra, O., Štych, P., Walker, S. \& Radeloff V.C. (2014). Forest and agricultural land change in the Carpathian region - a meta-analysis of long-term patterns and drivers of change. Land Use Policy, 38, 685-697. DOI : 10.1016/j.landusepol.2014.01.012.

Naughton-Treves, L., Holland, M. B., \& Brandon, K., (2005). The role of protected areas in conserving biodiversity and sustaining local livelihoods. Annual Review of Environment and Resources, 30, 219-252. https://doi.org/10.1146/annurev.energy.30.050504.164507.

Olah, B., Boltižiar, M., (2009). Land use changes within the Slovak biosphere reserves' zones. Ecology, 28, 127-142. DOI: 10.4149/ekol_2009_02_127

Opršal, Z., Kladivo, P., Machar, I. (2016). The role of selected biophysical factors in long-term land-use change of cultural landscape. Applied Ecology and Environmental Research 14(2), 23-40. http://dx.doi.org/10.15666/aeer/1402_023040

Pazúr, R., Bolliger, J., (2017). Land changes in Slovakia: Past processes and future directions. Applied Geography 85, 163-175. https://doi.org/10.1016/j.apgeog.2017.05.009

Pazúr, R, Feranec, J., Štych, P., Kopecká, M., Holman, L., (2017). Changes of urbanised landscape identified and assessed by the Urban Atlas data: Case study of Prague and Bratislava. Land Use Policy 61, 135-146. https://doi.org/10.1016/j.landusepol.2016.11.022.

Pešout, P., (2010). Doplnění soustavy chráněných krajinných oblastí v České republice [Completing the Protected Landscape Area Network in the Czech Republic]. Ochrana prírody 1, 6-11.

Pietrzyk-Kaszynska A., Cent J., Grodzinska-Jurczak M., Szymanska, M., (2012). Factors influencing perception of protected areas - The case of Natura 2000 in Polish Carpathian communities. Journal for Nature Conservation 20, 284-292. https://doi.org/10.1016/j.jnc.2012.05.005.

$\mathrm{R}$ Core Team (2019). R: A language and environment for statistical computing. $\mathrm{R}$ Foundation for Statistical Computing, Vienna, Austria. Retrieved December 8, 2020, from https://www.R-project.org/. 
Romportl D. (ed), (2017). Atlas fragmentace a konektivity terestrických ekosystémů v České republice [Atlas of landscape fragmentation and connectivity of terrestrial ecosystems in Czech Republic]. AOPK ČR, Praha, ISBN 978-80-88076-50-6.

Sklenička, P., Šímová, P., Hrdinová, K., Salek, M., (2014). Changing rural landscapes along the border of Austria and the Czech Republic between 1952 and 2009: Roles of political, socioeconomic and environmental factors. Applied Geography 47, 89-98. https://doi.org/10.1016/j.apgeog.2013.12.006.

Skokanová, H., Eremiášová R., (2013). Landscape functionality in protected and unprotected areas: Case studies from the Czech Republic. Ecological Informatics 14, 71-74. https://doi.org/10.1016/j.ecoinf.2012.11.007.

Skokanová, H., Falt’an, V., Havlíček, M., (2016). Driving forces of main landscape change processes from past 200 years in Central Europe - differences between old democratic and post-socialist countries. Ekológia (Bratislava), 35, 50-65. DOI: 10.1515/eko-2016-0004

Skokanová, H., Havlíček, M., (2018). Vývoj krajinného pokryvu v chráněné krajinné oblasti Brdy za posledních 180 let. Bohemia Centralis, 34, 31-49.

Štych, P., Kabrda, J., Bičík, I., Lastovicka, J., (2019). Regional Differentiation of Long-Term Land Use Changes: A Case Study of Czechia. Land, 8, 165. https://doi.org/10.3390/land8110165.

Sýkora, L., Bouzarovski, S., (2012). Multiple Transformations: Conceptualising the Post-communist Urban Transition. Urban Studies 49(1), 43-60. DOI: 10.1177/0042098010397402.

Uuemaa, E., Antrop, M., Roosaare, J., Marja, R., Mander, Ü., (2009). Landscape Metrics and Indices: An Overview of Their Use in Landscape Research. Living Rev. Landscape Research 3. http://dx.doi.org/10.12942/lrlr-2009-1.

Žoncová, M., (2020). Land Cover Changes in Protected Areas of Slovakia Between 1990 and 2018. Acta Geographica Slovenica 60(2), 71-89. https://doi.org/10.3986/AGS.7996. 
APPENDiX A: land cover flows for selected time period and each PLA.

\begin{tabular}{|c|c|c|c|c|c|c|c|c|c|c|}
\hline $\begin{array}{l}\text { Land cover flows } \\
\text { larger than } 1 \% \text { of } \\
\text { study area (whole } \\
\text { study period) in \% }\end{array}$ & $\begin{array}{l}\text { Bílé } \\
\text { Karpaty }\end{array}$ & $\begin{array}{l}\text { Blanský } \\
\text { les }\end{array}$ & Broumovsko & $\begin{array}{l}\text { České } \\
\text { středohoří }\end{array}$ & $\begin{array}{c}\text { Český } \\
\text { kras }\end{array}$ & $\begin{array}{l}\text { Český } \\
\text { ráj }\end{array}$ & Pálava & $\begin{array}{l}\text { Slavkovský } \\
\text { les }\end{array}$ & $\begin{array}{l}\text { Žd'árské } \\
\text { vrchy }\end{array}$ & $\begin{array}{l}\text { Železné } \\
\text { hory }\end{array}$ \\
\hline $\begin{array}{l}\text { Arable land to } \\
\text { permanent grassland }\end{array}$ & 20.73 & 12.33 & 24.20 & 18.83 & 12.99 & 12.26 & 2.92 & 14.54 & 12.33 & 15.12 \\
\hline $\begin{array}{l}\text { Permanent grassland } \\
\text { to forest }\end{array}$ & 4.64 & 4.63 & 3.18 & 6.16 & 3.00 & 2.91 & 1.88 & 10.65 & 3.35 & 2.52 \\
\hline Arable land to forest & 4.63 & 1.61 & 3.31 & 4.76 & 4.77 & 3.49 & 2.74 & 2.03 & 1.76 & 2.26 \\
\hline $\begin{array}{l}\text { Arable land to built-up } \\
\text { area }\end{array}$ & 2.57 & 1.43 & 1.10 & 2.11 & 1.56 & 2.05 & 2.47 & & 1.73 & 1.78 \\
\hline $\begin{array}{l}\text { Permanent grassland } \\
\text { to arable land }\end{array}$ & 1.70 & 3.10 & 2.06 & 1.06 & & 1.52 & & & 2.97 & 2.77 \\
\hline $\begin{array}{l}\text { Forest to permanent } \\
\text { grassland }\end{array}$ & & & & & & & 1.74 & & & \\
\hline $\begin{array}{l}\text { Arable land to garden } \\
\text { and orchard }\end{array}$ & 1.78 & & & 1.53 & & 1.92 & & & & \\
\hline $\begin{array}{l}\text { Permanent grassland } \\
\text { to built-up areas }\end{array}$ & & & & 1.37 & & & & & & \\
\hline $\begin{array}{l}\text { Garden and orchard to } \\
\text { arable land }\end{array}$ & & & & 1.24 & & & & & & \\
\hline
\end{tabular}




\section{Garden and orchard to}

permanent grassland

Arable land to 17.86

vineyard

Vineyard to arable

land

Arable land to

1.18

recreational area

\begin{tabular}{|c|c|c|c|c|c|c|c|c|c|c|}
\hline Land cover flows & Bílé & Blanský & Broumovsko & České & Český & Český & Pálava & Slavkovský & Žd'árské & Železné \\
\hline larger than $1 \%$ of & Karpaty & les & & středohoří & kras & ráj & & les & vrchy & hory \\
\hline
\end{tabular}

study area

(1950s-1990) in \%

Arable land to

7.26

7.14

14.25

8.79

6.69

6.44

1.99

5.29

5.06

7.33

permanent grassland

Permanent grassland

$2.91 \quad 3.65$

2.30

3.86

$1.37 \quad 1.99$

1.27

7.52

2.44

1.89

to forest

Arable land to forest

2.68

1.23

2.31

2.86

$1.52 \quad 2.61$

1.09

1.53

1.28

1.57

Arable land to built-up

1.79

1.48

$1.34 \quad 1.57$

1.26

1.41

area

Permanent grassland

3.17

5.20

3.61

5.42

1.36

4.31

7.64

5.99

4.91

to arable land

Forest to permanent 
grassland

Arable land to garden

and orchard

Permanent grassland

to built-up areas

Garden and orchard to

arable land

Garden and orchard to

permanent grassland

Arable land to

vineyard

Vineyard to arable

2.98

land

Arable land to

recreational area

Built-up area to 1.14

permanent grassland

Forest to arable land

2.71

\begin{tabular}{|c|c|c|c|c|c|c|c|c|c|c|}
\hline Land cover flows & Bílé & Blanský & Broumovsko & České & Český & Český & Pálava & Slavkovský & Žd'árské & Železné \\
\hline larger than $1 \%$ of & Karpaty & les & & středohoří & kras & ráj & & les & vrchy & hory \\
\hline
\end{tabular}

study area

(1990-present) in \% 


\begin{tabular}{|c|c|c|c|c|c|c|c|c|c|c|}
\hline $\begin{array}{l}\text { Arable land to } \\
\text { permanent grassland }\end{array}$ & 17.22 & 8.22 & 13.45 & 16.35 & 7.03 & 9.08 & 2.90 & 16.54 & 11.29 & 11.21 \\
\hline $\begin{array}{l}\text { Permanent grassland } \\
\text { to forest }\end{array}$ & 3.33 & 2.14 & 2.44 & 4.63 & 3.76 & 2.15 & 1.49 & 4.61 & 1.64 & 1.80 \\
\hline Arable land to forest & 1.62 & & & 1.22 & 1.41 & 1.17 & 2.11 & & & 1.07 \\
\hline $\begin{array}{l}\text { Arable land to built-up } \\
\text { area }\end{array}$ & & & & & & & 1.01 & & & \\
\hline $\begin{array}{l}\text { Permanent grassland } \\
\text { to arable land }\end{array}$ & & & 1.27 & & & & & & & 1.01 \\
\hline $\begin{array}{l}\text { Forest to permanent } \\
\text { grassland }\end{array}$ & & 1.02 & & 1.37 & & & & 1.12 & & \\
\hline $\begin{array}{l}\text { Arable land to garden } \\
\text { and orchard }\end{array}$ & & & & & & & & & & \\
\hline $\begin{array}{l}\text { Permanent grassland } \\
\text { to built-up areas }\end{array}$ & & & 1.17 & 1.02 & & 1.03 & & & & \\
\hline $\begin{array}{l}\text { Garden and orchard to } \\
\text { arable land }\end{array}$ & & & & & & & & & & \\
\hline $\begin{array}{l}\text { Garden and orchard to } \\
\text { permanent grassland }\end{array}$ & & & & & & & & & & \\
\hline $\begin{array}{l}\text { Arable land to } \\
\text { vineyard }\end{array}$ & & & & & & & 14.06 & & & \\
\hline $\begin{array}{l}\text { Vineyard to arable } \\
\text { land }\end{array}$ & & & & & & & 1.31 & & & \\
\hline
\end{tabular}


Arable land to

recreational area

Built-up area to

permanent grassland

Forest to arable land 
Journal of Landscape Ecology (2021), Vol: 14 / No. 3

APPENDIX B: landscape metrics for all land cover classes and selected time horizons

\begin{tabular}{|c|c|c|c|c|c|c|c|c|c|}
\hline & \multicolumn{3}{|c|}{ 1950s } & \multicolumn{3}{|c|}{1990} & \multicolumn{3}{|c|}{ Present } \\
\hline & ED & MPS & NumP & ED & MPS & NumP & ED & MPS & NumP \\
\hline Other area & 0.28 & 2.91 & 159 & 0.28 & 6.08 & 117 & 0.23 & 8.48 & 82 \\
\hline Arable land & 33.50 & 46.41 & 3548 & 25.04 & 52.39 & 2628 & 12.67 & 36.25 & 1945 \\
\hline $\begin{array}{l}\text { Permanent } \\
\text { grassland }\end{array}$ & 30.40 & 13.10 & 6126 & 29.48 & 12.76 & 6021 & 33.02 & 25.79 & 4822 \\
\hline $\begin{array}{l}\text { Garden and } \\
\text { orchard }\end{array}$ & 2.12 & 4.98 & 947 & 2.25 & 5.89 & 960 & 2.33 & 4.30 & 1174 \\
\hline $\begin{array}{l}\text { Vineyard and } \\
\text { hop garden }\end{array}$ & 0.55 & 6.99 & 218 & 0.45 & 23.90 & 85 & 0.60 & 29.05 & 92 \\
\hline Forest & 22.00 & 60.14 & 2917 & 25.68 & 60.41 & 3255 & 27.59 & 60.29 & 3509 \\
\hline Water area & 0.46 & 6.65 & 205 & 0.72 & 6.84 & 311 & 0.79 & 6.02 & 370 \\
\hline Built-up area & 7.86 & 7.46 & 2480 & 9.34 & 9.59 & 2585 & 10.56 & 10.32 & 2749 \\
\hline $\begin{array}{l}\text { Recreational } \\
\text { area }\end{array}$ & 0.10 & 4.18 & 46 & 0.35 & 4.06 & 169 & 0.55 & 5.22 & 227 \\
\hline
\end{tabular}

